\title{
Research on International Education Mode of Accounting Talents
}

\author{
Haifan $\mathrm{Lu}^{1, *}$ \\ ${ }^{1}$ Accounting School, Guangdong University of Foreign Studies, Guangzhou, 510006, China \\ *Corresponding author. Email: susielu@163.com
}

\begin{abstract}
The internationalization of accounting puts forward new requirements for the training of accounting talents. This paper tries to solve the problem of how to cultivate international compound accounting talents in accounting major in Colleges and universities. Focusing on the domestic international undergraduate accounting education, this paper analyzes the quality that international compound accounting talents should have. By analyzing the current situation of the training of international undergraduate accounting talents in China, it is found that the existing training system has some problems, such as unclear training objectives, unreasonable curriculum system and ignoring ability education. It is pointed out that we should strengthen the construction of teaching materials and improve teaching methods, Optimize the teaching quality and effectively promote the construction of teachers to build a more reasonable and advanced international accounting talent training mode.
\end{abstract}

Keywords: international, accounting talents, ability, trading

\section{INTRODUCTION}

In recent years, the emerging global financial crisis has made theorists and practitioners more aware of the importance of establishing a set of high-quality and globally unified international financial reporting standards system and training international accounting talents. International accounting talents are essential to accounting globalization, and accounting internationalization is also the direct motivation for the internationalization of accounting talents. With the in-depth development of China's economic globalization, the transnational operation of enterprises and the cross-border flow of capital are becoming more and more frequent. There is an urgent need for a large number of international accounting professionals. However, there is a shortage of high-quality compound accounting talents who are familiar with international market rules and domestic laws and regulations[1]. In particular, there is a serious shortage of talents who are familiar with international accounting standards. There is a big gap in the demand for international accounting talents. Taking accounting internationalization as the background, it is urgent to improve the quality of accounting practitioners and speed up the training of international accounting talents[2]. Therefore, in the process of China's economic globalization, it is necessary to reflect on the training mode of accounting students in Colleges and universities, and explore the new talent training mode.

\section{BASIC QUALITY REQUIREMENTS OF INTERNATIONAL ACCOUNTING TALENTS}

International accounting talents should be "international, high-quality and application-oriented compound talents". Specifically, they should be proficient in Chinese accounting standards and systems, familiar with international accounting standards and practices, proficient in using one or more foreign languages and computers, have comprehensive quality and adaptability, and be able to engage in accounting in various enterprises, firms and government departments. Specifically, there are the following aspects:

\subsection{Comprehensive Professional Knowledge}

International accounting talents need to have a reasonable knowledge structure. Mastering comprehensive professional knowledge is the basic premise of cultivating accounting professional skills[3]. The work of accounting revolves around accounting information. The knowledge of accounting, audit, financial management and taxation constitute the core of accounting knowledge. In addition, they should also have legal knowledge, organizational and enterprise knowledge, as well as information technology knowledge, so as to provide background and tools for the application of core knowledge and vocational skills. In addition, international accountants should also have an international professional vision, be familiar with 
international accounting standards, understand foreign market operation rules and relevant laws and regulations, and master the latest industry knowledge.

\subsection{Practical Ability}

Accounting professional skills are the abilities to use professional knowledge reasonably and effectively in the professional environment and maintain professional values, ethics and attitudes, which means strong ability to analyze, solve problems and continue to learn[4]. Professional judgment is the core of the above skills. International accounting talents should take the cultivation and improvement of professional judgment ability as the top priority of accounting education. Good professional judgment needs to be based on accounting experience and knowledge, based on the applicable professional standard framework, and guaranteed by due attention, objectivity and integrity. Therefore, international accounting talents should have strong logical ability and be able to find connections from complex financial and non-financial information for induction and analysis, so as to supervise the economic operation of enterprises and solve various financial problems effectively.

\subsection{Awareness of Professional Ethics}

International talents should have high ideological awareness, strong legal awareness and sense of responsibility, be rigorous and meticulous in their work, and have a strong sense of service. Therefore, in the process of training international accounting talents, we should set up corresponding courses and professional practice, cultivate students' correct professional ethics, establish their awareness of safeguarding public interests and fulfilling social responsibilities, the awareness of continuous progress and lifelong learning, and the awareness of abiding by laws and regulations. Only in this way can we cultivate international high-level accounting talents with high moral standards and strict self-discipline for the accounting industry.

\subsection{Innovation Ability}

With the increasing uncertainty of the economic environment, new economic businesses are also emerging. The existing accounting standards may not provide comprehensive business processing guidance for the emerging new economic businesses. This requires accountants to have innovation ability in the face of new business, that is, to break through the thinking set, comprehensively use the existing knowledge and internal and external conditions, and creatively understand, analyze, raise and solve problems. When facing the original economic business, accountants should also explore different solutions, design diversified and innovative solutions, and improve efficiency and effect on the premise of ensuring the authenticity and reliability of information. Accountants should also be able to constantly explore and innovate according to the actual needs or new circumstances of the new environment and with reference to the existing standards at home and abroad, so as to form an accounting method system that can meet the requirements of the new environment and new business.

In order to meet the ability requirements of the society for accounting talents, universities should analyze the defects of the existing training mode, explore the professional ability of accounting talents required by the society, adjust the education and training objectives, make full use of international cooperation, and build an accounting postgraduate training mode suitable for the new environment.

\section{PROBLEMS IN THE TRAINING MODE OF ACCOUNTING TALENTS IN COLLEGES AND UNIVERSITIES}

\subsection{Unclear Training Objectives}

At present, the training objectives of most universities and colleges for accounting talents are too vague, such as "training international accounting professionals with all-round development". Due to the lack of specific standards, it is difficult to implement such goals. The training of accounting talents has different levels. The objectives of each level are different from undergraduate accounting education to master's and doctor's training. Even in the accounting education at the undergraduate level, there are differences in whether to cultivate accounting professionals or generalists, and whether to focus on theory or practice. However, these details are not specified in the training objectives of accounting major in many colleges and universities. This kind of vague training goal often leads to students' poor application ability after graduation.

\subsection{Unreasonable Curriculum System}

There are some defects in the curriculum system of Accounting Specialty in Colleges and universities. First of all, in terms of curriculum, courses involving internationalization are not in the scope of compulsory courses, and there are few class hours, which makes it difficult for teachers to introduce the contents of internationalization in detail in limited class hours. The core courses often focus on the business examples of domestic enterprises, and rarely involve international business. Secondly, there is a lack of economic and trade management courses, such as international economy and trade, international business negotiation, international finance, multinational company management and other 
non accounting courses closely related to international economy and trade have not been included in the curriculum system. The knowledge structure corresponding to such a curriculum system does not meet the requirements of the current society for accountants who are familiar with international accounting theory and practice. Such a curriculum system leads to students' lack of understanding of international business and difficult to have an international vision.

\subsection{Neglect Ability Education}

Different from most other disciplines, the operability of accounting is very strong, but at present, although accounting education in colleges and universities pays great attention to the explanation of professional knowledge, it often despises students' practical application ability. Although many accounting majors in Colleges and universities often set up one or two practical courses, practical courses focus on assessing the standardization and correctness of accounting treatment. Generally, students are only required to master the basic accounting operation skills, which is often far from the operation in practice. In addition, the existing educational model also ignores the cultivation of students' analytical ability. Due to the increasingly complex economic environment, economic business is often not as simple and standardized as the examples in textbooks, which requires accountants to have strong professional analysis ability, and accountants to make correct analysis and judgment according to the basic standards even in the face of unfamiliar business. However, the existing training model focuses on the results rather than the process, so it ignores the evaluation of students' autonomous learning and analysis ability.

\section{REFORM TO ACHIEVE THE GOAL OF INTERNATIONAL ACCOUNTING TALENT TRAINING}

\subsection{Improve the Curriculum System}

The existing curriculum system of accounting in colleges and universities can not meet the requirements of accounting internationalization development at this stage[5]. It is necessary to reform and innovate the curriculum system according to the quality that international accounting talents should have. Therefore, in the course setting, we should take cultivating students' professional knowledge structure and professional ability as the basic goal of the course setting, and effectively integrate the quality and ability required by international accounting talents into the course system. Firstly, we should improve and simplify the existing curriculum system, that is, we should not only add international accounting courses and international accounting standards, but also integrate the existing accounting curriculum system to avoid duplication of contents between courses. Secondly, the curriculum should pay attention to the comprehensiveness of disciplines and the integrity of knowledge, and increase the knowledge of relevant disciplines such as economics and management. Third, pay more attention on practical training. In the process of training accounting professionals, we should change the traditional idea of "emphasizing theory over practice" and strengthen practical training, so as to meet the needs of employers.

\subsection{Optimization Teaching Materials}

Teaching materials are the main carrier of knowledge, so strengthening the construction of teaching materials is the top priority in the training of international accounting talents. In the construction of teaching materials, we should update the old contents in time, create conditions and try to keep pace with internationalization. First of all, update the content of the original textbook system, increase the content of international accounting in the textbook system, and realize the internationalization of the textbook as soon as possible, so that students can understand international accounting standards and relevant international practices and master the latest international trends in time. Secondly, accounting teachers should absorb the new achievements in the current western accounting theories and methods and the new theories of the development of other related disciplines into the existing teaching materials, so as to make the content of the teaching materials keep pace with social needs. Finally, the original textbooks of relevant disciplines shall be properly introduced, adapted, selected according to the requirements of the syllabus of each discipline, and properly supplemented with Chinese textbooks to meet the teaching needs of this discipline.

\subsection{Improve Teaching Methods and Optimize Teaching Quality}

At present, there are still traditional indoctrination teaching methods in the training of accounting talents in colleges and universities in China. Such teaching methods are difficult to stimulate students' enthusiasm and can not teach students according to their aptitude, but will restrict and hinder students' development. According to the objectives of undergraduate teaching of international accounting major and the needs of society, in the teaching methods, case teaching method could be used, imply the problem-oriented teaching method, introduce the linkage teaching method of self-study and discussion. The teaching method should be changed from one-way "indoctrination" to interactive teaching based on discussion with students in order to cultivate students' innovative ability. In the content of lectures, we should pay equal attention to theoretical knowledge and practical knowledge, focus on cultivating students' ability to analyze and solve problems independently, introduce 
case teaching and increase the proportion of experimental courses.

\subsection{Improve Teaching Methods}

The internationalization of teachers is the key to the internationalization of accounting education. We can improve the teaching staff through the following aspects: first, clarify the guiding ideology of teaching staff construction, and build a teaching staff with optimized structure, high quality and innovative ability in line with the orientation and objectives of running a school. Secondly, establish a regular mechanism for training, exchange and further study of bilingual teachers, maintain a long-term and stable teacher training plan with other professional colleges and universities in the world. Third, establish the practice mechanism of young teachers, select some young teachers to practice in practical departments, promote the accumulation and enrichment of professional teachers' professional experience and skills, better realize the integration of theory and practice, and provide sufficient international teachers' guarantee for the sustainable development of accounting internationalization.

\section{CONCLUSION}

The demand of economic globalization for international compound accounting talents is increasing day by day. At present, there is a big gap between the training mode of accounting talents in Colleges and universities and the requirements of society for accounting talents. According to the social requirements for accounting professional quality, the school can adjust the focus of professional quality training, reconstruct the curriculum system, improve teaching methods, optimize the teaching team, so as to achieve the teaching purpose of internationalization of accounting talents, so as to cultivate accounting talents that meet the needs of the society.

\section{ACKNOWLEDGMENT}

Thanks for the support of Advanced education teaching research and reform project of Guangdong University of Foreign Studies: One belt, one road, "small language + accounting" talent training mode.

\section{REFERENCES}

[1] Z.L.Liao. "Research on the training mode of international accounting talents -- from the perspective of talent demand of colleges and universities and multinational enterprises". PR Magazine,2022(11), pp. 111-112.

https://kns.cnki.net/kcms/detail/detail.aspx?dbcode $=\mathrm{C}$ JFD\&dbname $=$ CJFDLAST2020\&filename $=$ GGGJ202 $011055 \&$ uniplatform $=\mathrm{NZKPT} \& \mathrm{v}=\mathrm{I} 75 \mathrm{oDXq} 8 \mathrm{sCd} 6 \mathrm{q} 0$ FxSk4yRq1lx\%25mmd2BIVsqHv7Wgwljs3Y84c4Q2 1BcUxEnMq\%25mmd2FculMf28

[2] Y. Yu . "Research on ACCA international accounting talent training model.” Accounting learning. 2021, (17). pp.

171-173.https://kns.cnki.net/kcms/detail/detail.aspx?d bcode $=$ CJFD\&dbname $=$ CJFDLAST2021 \&filename $=$

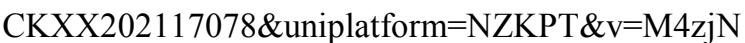
WXrXmM7SqZmbzWcRonuCU6uJ41H5\%25mmd2F 69C0EBmHSJrwqPtmiNpuLmoFZmc\%25mmd2BBc

[3] S.B. Yu. "Training mode and target construction of international accounting talents in Colleges and universities." Modern enterprise. 2021, (09). pp.138-139.

https://kns.cnki.net/kcms/detail/detail.aspx?dbcode $=\mathrm{C}$ JFD\&dbname $=$ CJFDAUTO\& filename $=$ XDQY20210 $9072 \&$ uniplatform $=$ NZKPT \&v $=8 X N 6$ WBR263U $\% 25$ mmd2BWcp39ELSVgRaFcEFE5q1qAI3L7fPsXqvGa e7CWIBf0TvVeOshVnf

[4] Wang Yong, Zhao Zhenzhi. "International accounting major, students' English ability and international accounting talent training - a recursive model test based on the questionnaire data of ACA major in Colleges and universities in Shandong Province." Accounting communication. 2018, (34), pp. 43-46.

https://kns.cnki.net/kcms/detail/detail.aspx?dbcode $=\mathrm{C}$ JFD\&dbname $=$ CJFDLAST2019\&filename $=$ CKTX20 $1834010 \&$ uniplatform $=$ NZKPT\&v=YtJ1Inj8E5QJOtq $3 \mathrm{~W} 73 \mathrm{bD} \% 25 \mathrm{mmd} 2 \mathrm{~F} 3 \mathrm{nlN} 0 \mathrm{u} 6 \mathrm{Cm} 2 \mathrm{lCXkkuU} \% 25 \mathrm{mmd}$ 2BouZ07Qx5gIP9AP\%25mmd2BI9wbUml1M

[5] Cai Lei, Zhao Jiaxin. "Research on the training mode of applied undergraduate accounting talents from an international perspective." Modern economic information. 2018, (01). pp.393-395.

https://kns.cnki.net/kcms/detail/detail.aspx?dbcode $=\mathrm{C}$ JFD\&dbname $=$ CJFDLAST2018\&filename $=$ XDJZ20 1 $801323 \&$ uniplatform $=$ NZKPT \& $=\mathrm{f} \% 25 \mathrm{mmd} 2 \mathrm{BKu} 5 \mathrm{a}$ AydQbRi31Sboj\%25mmd2FrKFUd1kzJoWZXPxKdA g8wHOrXeccuZ4\%25mmd2F2Qd7yF1vbN1b 